\title{
QUALILITATIVE DISTRIBUTION OF SPRAY DEPOSIT BY USING SOME GROUND SPRAYING TECHNIQUES ON OLIVE TREES FOR CONTROLLING PARLATORIA OLEAE ( COLVEE ) (HEMIPTERA : DIASPIDIDAE)
}

\author{
AMMAR, A. E., M. A. HINDY and M. M. HELMY \\ Spray technology research department, Plant Protection Research Institute, ARC, Giza, Egypt
}

(Manuscript received 25 June 2012)

\begin{abstract}
The aim of this study is to evaluate the specific ground sprayer units for controlling Parlatoria oleae Colvee infesting olive trees by using different pesticides. The experiments included spray volume coverage on the olive trees and sources of pollution as pesticides lost on ground and drift spray solution. The tested sprayer units were conventional ground motor sprayer with hydraulic spray gun (860 l/fed.), knapsack motor sprayer (Taral 518 ) with its original pneumatic atomizer (430 l/fed.). It is worth mentioning that, this model has its poster pum. In a modification for the taral motor its atomizer was replaced by three Tee-Jet nozzles (D5-45 or D8-45 as 430 and $568 \mathrm{l} /$ fed., respectively) fitted perpendicular to the air stream. In the case of D5-45 modification the conventional ground motor sprayer tank was used as source for spray solution under pressure. Super masrona (mineral spray oil) at the rate of $1-5 \%$ alone or at the rate of $1 \%$ mixed with organophosphorous Sumithion $50 \%$ EC at rate of $0.15 \%+0.5 \mathrm{gm} /$ liter fluoresin sodium were sprayed in this experiment. Qualitative distribution of droplets using water sensitive cards indicated that, conventional ground motor sprayer has the highest number of droplets $/ \mathrm{cm}^{2}$ and highest droplet sizes VMD $\mu \mathrm{m}$ per droplets over most of measured spots. Data also showed that, conventional ground motor sprayer should be used twice spray volume and subsequently twice sprays material (pesticide) as the modified sprayer. Taral motor sprayer with three Tee-Jet nozzles D8-45 came in between. Concerning the lost spray solution on the ground and the spray drift, conventional ground motor sprayer caused the highest lost of spray solution on the ground and drift spray followed by Taral motor sprayer with three Tee-Jet nozzles D8-45 and the least was taral motor sprayer with three Tee-Jet nozzles D5-45.

The presented results indicated the superiority of the tested Taral motor sprayer with Tee-Jet nozzles D5-45 (430 l/fed.) over the other three tested sprayers in minimizing the time of spraying, reducing spray volume and pollution under Egyptian conditions.
\end{abstract}




\section{INTRODUCTION}

The olive plantation area in Egypt reached 108,322 feddans in year 2000 according to (Agricultural Economic and statistics department, Ministry of Agriculture, Egypt 2000). Scale insects (hemiptera: Coccoidea) are considered as an important group attacking olive trees affecting health, productivity fruit yield and oil quantity and quality. Parlatoria oleae Colvee (Hemiptera: Diaspididae) is one of the most important scale insect pests which cause serious damage to olive trees in many parts of the world. The insect attacks most parts of the tree and the infestation in mainly concentrated on the trunks, branches, twigs and fruits.

The common method for controlling these pests under local conditions is spraying the trees with mineral oils and organophosphorous insecticides with a high spraying rate volume which consumes excessive amounts of chemicals ware and time, causing environmental pollution especially to the soil, air, fruits and irrigation water. Regarding, minimizing the hazards to the environment by decreasing drift (Amberg and butter, 1970) and dropped under tree, the cost and time of control operations and in the meantime increasing the efficiency and determining the timing of application. The aim of this study was conducted to evaluate specific spray techniques for controlling $P$. oleae using mineral oil or mixed with organophosphorous pesticides and florosien sodium dye. Evaluation indicators included the following points, spraying volume factor, qualititative deposits on the olive trees and sources of pollution including spray solution lost on ground and drift by air were considered.

\section{MATERIALS AND METHODS}

\section{1- Equipment and spraying techniques}

Four equipment were used in field experiments as following

1-1- Traditional ground motor sprayer with 300 litre tank, $6 \mathrm{Hp}$ power engine and $7-10 \mathrm{~kg} / \mathrm{cm}^{2}$ operating pressure with spraying volume of $860.0 \mathrm{l} / \mathrm{fed}$.

1-2- Pneumatic knapsack motor sprayer (taral 518) with poster and 20 litres tank the flow rate of operative 2 was used to emit $2 \mathrm{l} / \mathrm{min}$, for spraying volume of $430.0 \mathrm{l} /$ fed three disc-core (hollow cone) nozzles were fitted to a short plastic tube $(7.5 \mathrm{~cm}$ in diameter) perpendicular to its wall, (Plate 1). This modification was designed to replace the taral (518) plastic atomizer. The advantage of this modification that, it can be fitted with different cores and discs to give specific flow rates at ranges of pressure (Mcmechan and Havorson 1997). 
1-3- Modified Taral with three Tee-Jet nozzle D8-45

Knapsack motor sprayer, ( spraying volume of $495 \mathrm{l} / \mathrm{fed}$.).

1-4- Modified Taral with three Tee-Jet nozzles D5-45

Knapsack motor sprayer/conventional motor sprayer (spraying volume of 430 I/fed).

The same previous design with Tee-Jet nozzles D5-45 nozzles was used receiving the spray solution from the traditional motor spray and the knapsack sprayer as source of air only (Abou Setta, 1981).

\section{2- Calibration of used sprayers}

The flow rate of each spray equipment was determined. The time required to spray an average olive tree using tested sprayers to drip was evaluated. Therefore, the spray volume per tree was determined for each used equipment as shown in Table (1)

\section{3- Insecticides used}

3-1- Sumithion (Fentrothion) $50 \%$ EC. of the recommended rate of application of $0.15 \%$.

3-2- super masrona (mineral oil 94\% EC) with recommended application rate of $1.5 \%+(0.5 \mathrm{gm} /$ liter fluorescein sodium (Dean et. al. 1961)

Each of the four equipment was tested either using super masrona oil at the rate of $1.5 \%$ or mixture of super masrona oil at the rate of $1 \%$ plus sumithion and the rate of $0.15 \%$. 
(HEMIPTERA : DIASPIDIDAE)

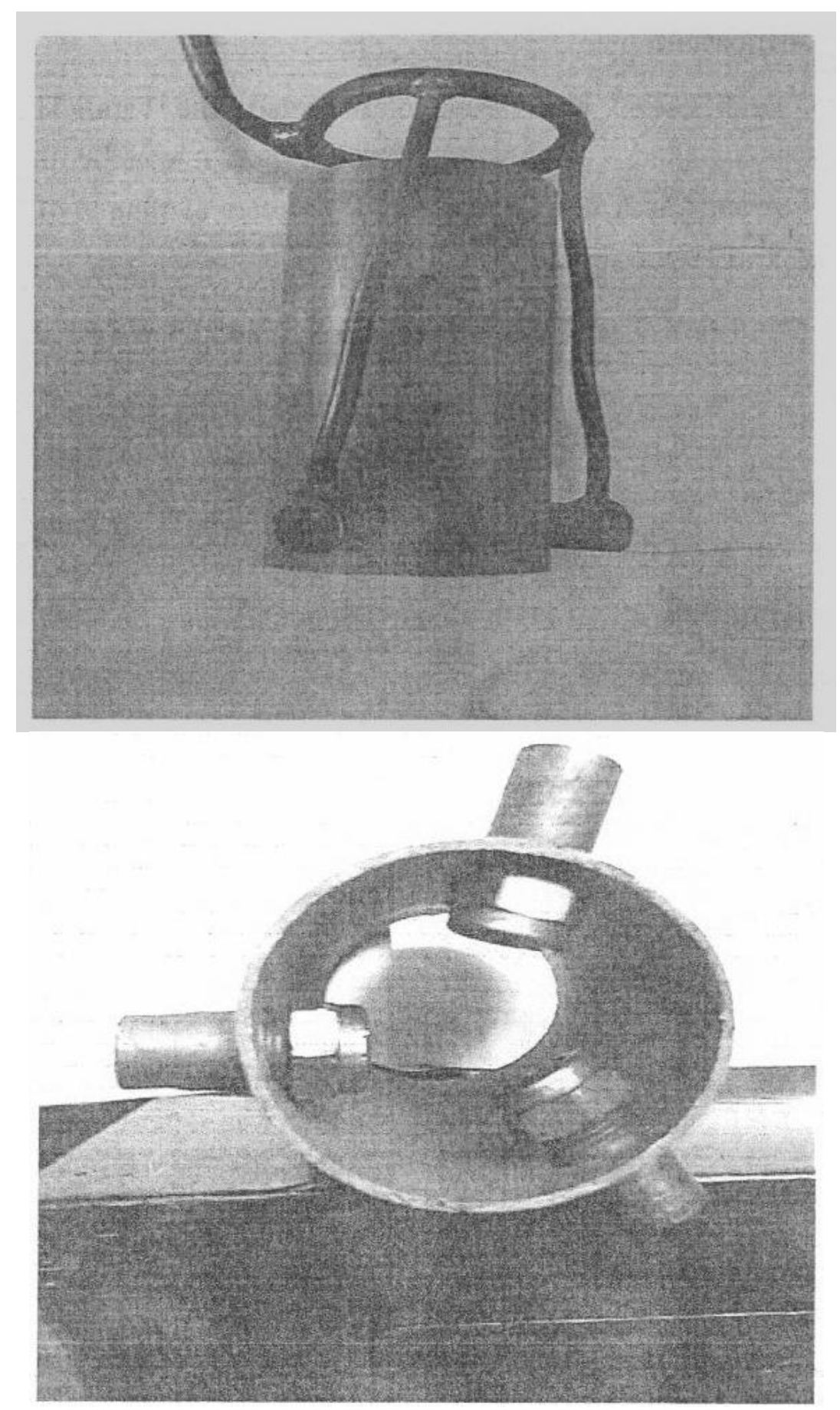

Plate 1. Modification of three disc core nozzles where fitted to a plastic tube mounted on (Taral 518) as a new spray unit (After Abou Setta 1981). 
Table 1. Techno-operational data of different spray units tested to control $P$. oleae on olive trees.

\begin{tabular}{|c|c|c|c|c|}
\hline Item & \multicolumn{4}{|c|}{ Value / specification } \\
\hline Spray unit & Conventional & \multicolumn{3}{|c|}{ Taral motor $518^{* *}$} \\
\hline Nozzle type & $\begin{array}{l}\text { Spray gun: } \\
\text { hollow cone }\end{array}$ & $\begin{array}{l}\text { (Hydraulic) } \\
\text { Three nozzlesD5-45 }\end{array}$ & $\begin{array}{l}\text { (Pneumatic) } \\
\text { Aperture } 2\end{array}$ & $\begin{array}{c}\text { (Pneumatic) } \\
\text { Three nozzles } \\
\text { d8-45 }\end{array}$ \\
\hline $\begin{array}{c}\text { Mean flow rate } \\
\text { (I./min.) }\end{array}$ & 15 & 2 & 2 & 3.3 \\
\hline $\begin{array}{c}\text { Time of spray } \\
\text { (min./tree) }\end{array}$ & $40 \mathrm{sec}$. & 2.5 & 2.5 & 2 \\
\hline $\begin{array}{c}\text { Spraying volume } \\
(1 . / \text { tree }) \\
\end{array}$ & 10 & 5 & 5 & 6.6 \\
\hline $\begin{array}{c}\text { Spraying volume (I./ } \\
\text { fed.) }\end{array}$ & 860 & 430 & 430 & 568 \\
\hline Operational pressure & & $7-10$ & $\left.\mathrm{~m}^{2}\right)$ & \\
\hline No. of nozzles & one & Three nozzles D5-45 & one & $\begin{array}{c}\text { Three nozzles } \\
\text { D8-45 }\end{array}$ \\
\hline Insecticide used rate & Sumithion 0.1 & $\begin{array}{r}\text { S. Masr. } 1.5 \% \text { or Su } \\
\text { fluoresce }\end{array}$ & $\begin{array}{l}15 \%+\text { S. Mas } \\
\text { dium }\end{array}$ & $+0.5 \mathrm{gm} / \mathrm{liter}$ \\
\hline
\end{tabular}

* Average working speed around the tree was $20 \mathrm{~m} / \mathrm{min}$. in all treatments

** Taral motor 518 provided with poster pump in all treatments

\section{4- Experimental design}

This experiment was carried out on olive trees orchard (20 years old) at the beginning of Alexandria desert road at Giza, during mid of June 2004 to mid of September 2004. Average wind velocity was $2 \mathrm{~m} / \mathrm{sec}$., temperature $32 \mathrm{c}^{\circ}$ and relative humidity $55 \%$ during execution of the treatment (eight treatments) and nine trees for control. Selected trees were similar in size, shape, height and vegetation. All trees were homogenous in their infestation with $P$. oleae. Olive trees were planted at 6 meter spacing (about 116 trees/fed.).

\section{5- Spray assessment}

5-1- Qualitative distribution of droplets and its relation with spraying efficiency

5-1-1- in field: sensitive water strips were distributed at three levels of olive trees on two trees for each treatment in the four cardinal directions. At the 
peripheral, the core and the top of the tree. Nine spray receptors were located at ( 2 meters) to determine the drift spray by air around each treated as shown in Figure (1).

\section{5-1-2- in laboratory}

The water sensitive strips were collected the treated trees for all treatments. Droplets have been calculated by a specific lens (Strubin $x 15$ ) scaled monocular lens. The diameter data of the spots were corrected with knowledge of spread factor according to mass (1971) and converted to volume mean diameter and the number of droplets in square centimeter $\left(\mathrm{N} / \mathrm{cm}^{2}\right)$ was estimated according to Gabir et. al. 1982.

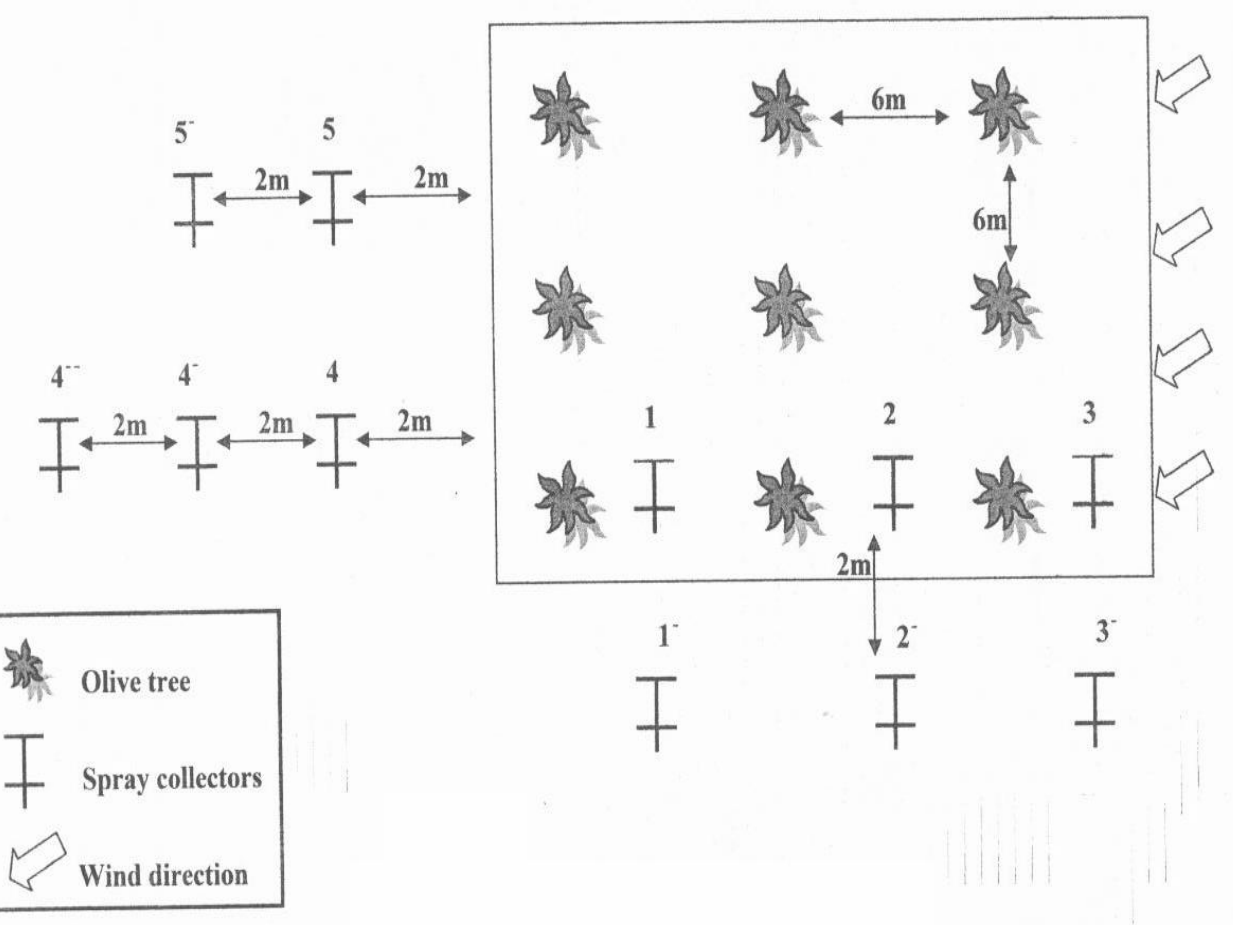

Fig 1. Experimental area and sampling lines

\section{RESULTS AND DISCUSSION}

\section{1- Qualitative distribution of droplets}

Results presented in Table (2) indicated general trend that conventional motor sprayer achieved the highest number of droplets $\mathrm{n} / \mathrm{cm}^{2}$ these results are samples of upper middle, lower parts of tree periphery and upper, middle, lower of tree core, respectively. Average numbers of droplets were $670,840,730$ and 740 per square 
centimeter. Conventional motor sprayer also achieved generally the highest values for VMD per droplet over most of the measured spots. The obtained results disagree with (Abdel-Moati, 1981) who reported that, with hydraulic nozzles, the increase of operating pressure and spray height caused are markable decrease of droplets diameter (VMD) accompanied with an increase in the number of droplets $\left(\mathrm{n} / \mathrm{cm}^{2}\right)$. Also disagree with (Gabir et. al., 1982) who found that, the droplets size (VMD) was decreased gradually while the numbers of droplets were increased consequently in concentration with the increase of spray height and pressure. Application on tree top, taral motor sprayer with three Tee-Jet nozzles D5-45 gave the lowest for VMD per droplet which was $290 \mu \mathrm{m}$.

Results concerning $\left(\mathrm{n} / \mathrm{cm}^{2}\right)$ for lost spray on ground surrounding the olive trees at horizontal levels using conventional motor sprayer and taral motor sprayer aperture 2 are presented in table (3) conventional motor sprayer lost spray on ground was presented by complete wash for the used cards. The $\left(\mathrm{n} / \mathrm{cm}^{2}\right)$ for taral motor sprayer aperture 2 ranged between 456-1000 with mean of 600. The presented results indicated the superiority of conventional motor in polluting soil.

Table 2. Droplet distribution of certain ground sprayers using spray solution (Super masrona $1.5 \%$ + Fluorescein sodium $0.05 \%$ ) on lateral branches of olive trees.

\begin{tabular}{|c|c|c|c|c|c|c|c|c|c|}
\hline Tree coverage & \multirow{3}{*}{\multicolumn{2}{|c|}{$\begin{array}{l}\text { Spraying } \\
\text { volume } \\
\text { L./fed }\end{array}$}} & \multicolumn{7}{|c|}{ Tree periphery } \\
\hline \multirow{2}{*}{ Card position } & & & & pper & & Middle & & & \\
\hline & & & $\mathrm{n} / \mathrm{cm}^{2}$ & $V m d \mu \mathrm{m}$ & $\mathrm{n} / \mathrm{cm}^{2}$ & Vmd & & $\mathrm{n} / \mathrm{cm}^{2}$ & $V m d \mu \mathrm{m}$ \\
\hline $\begin{array}{l}\text { Taral motor } \\
\text { aperture2 }\end{array}$ & \multicolumn{2}{|l|}{430} & 400 & 189 & 590 & \multicolumn{2}{|l|}{255} & 580 & 212 \\
\hline Taral motor (D5-45) & \multicolumn{2}{|l|}{430} & 600 & 78 & 490 & \multicolumn{2}{|l|}{78} & 500 & 104 \\
\hline Taral motor (D8-45) & \multicolumn{2}{|l|}{568} & 570 & 198 & 510 & \multicolumn{2}{|l|}{326} & 690 & 241 \\
\hline $\begin{array}{l}\text { Traditional ground } \\
\text { motor }\end{array}$ & \multicolumn{2}{|l|}{860} & 670 & 358 & 840 & \multicolumn{2}{|l|}{334} & 840 & 280 \\
\hline Tree coverage & \multicolumn{7}{|c|}{ Tree core } & \multicolumn{2}{|c|}{ Tree top } \\
\hline \multirow[b]{2}{*}{ Card position } & \multicolumn{3}{|c|}{ Upper } & \multicolumn{2}{|c|}{ Middle } & \multicolumn{2}{|c|}{ Lower } & & \\
\hline & $\mathrm{n} / \mathrm{cm}^{2}$ & Vmd $\mu$ & & $\mathrm{n} / \mathrm{cm}^{2}$ & $V m d \mu \mathrm{m}$ & $\mathrm{n} / \mathrm{cm}^{2}$ & $\begin{array}{l}\text { Vmd } \\
\mu \mathrm{m}\end{array}$ & $\mathrm{n} / \mathrm{cm}^{2}$ & $V m d \mu m$ \\
\hline $\begin{array}{l}\text { Taral motor } \\
\text { aperture2 }\end{array}$ & 730 & 221 & & 530 & 272 & 540 & 333 & 100 & 340 \\
\hline Taral motor (D5-45) & 630 & 47 & & 620 & 143 & 390 & 101 & 390 & 290 \\
\hline Taral motor (D8-45) & 440 & 290 & & 380 & 304 & 470 & 339 & 410 & 376 \\
\hline $\begin{array}{l}\text { Traditional ground } \\
\text { motor }\end{array}$ & 780 & 376 & & 730 & 330 & 740 & 419 & 220 & 413 \\
\hline
\end{tabular}


Table 3. Lost spray solution on ground surrounding olive trees at horizontal level.

\begin{tabular}{|c|c|c|c|c|}
\hline \multirow{2}{*}{ Card position } & \multicolumn{2}{|c|}{ Conventional motor } & \multicolumn{2}{c|}{ Taral motor aperture 2 } \\
\cline { 2 - 5 } & $\mathrm{n} / \mathrm{cm}^{2}$ & Vmd $\mu \mathrm{m}$ & $\mathrm{n} / \mathrm{cm}^{2}$ & Vmd $\mu \mathrm{m}$ \\
\hline \multirow{2}{*}{ North } & Wash & - & Wash & - \\
\hline South & Wash & - & 456 & 472 \\
\hline East & Wash & - & 456 & 407 \\
\hline West & Wash & - & 489 & 460 \\
\hline Average & Wash & - & 600 & 446 \\
\hline
\end{tabular}

\section{2- Drift assessment}

Results of Table (4) showed that, general trend indicated the efficacy of conventional motor sprayer achieving highest number of droplets $\mathrm{n} / \mathrm{cm}^{2}$. These results are of left, right and middle of horizontal and vertical level respectively. Average numbers of droplets were 264, 144 and 284, 188 per $\mathrm{cm}^{2}$. The mean size of droplets (VMD) increased by the increase of droplet numbers per $\mathrm{cm}^{2}$. The conventional motor sprayer gave generally the highest values for VMD per droplet over the measured spots.

Drift spray solution distribution on horizontal spray receptors by taral motor sprayer aperture 2 which indicate that the droplets $\mathrm{ncm} 2$ percentage left, right and middle upper was 100, 89 and 79 respectively, while theses percentages were 0,11 and 21 for the left, right and middle lower respectively(Table 4). Also presented drift spray solution distribution on vertical spray receptors by taral motor sprayer operator 2 which indicate that, the droplets $\mathrm{n} / \mathrm{cm} 2$ percentage left, light and middle upper were 0,53 and $43 \%$ respectively, while these percentages were 0,47 and 57 for the left, right and middle lower respectively. 
Table 4. Drift spray solution and their distribution on spray receptors during spaying olive trees.

\begin{tabular}{|c|c|c|c|c|c|c|}
\hline \multirow{2}{*}{ Spray units } & \multirow{2}{*}{\multicolumn{2}{|c|}{ Card position }} & \multicolumn{2}{|c|}{ Horizontal level } & \multicolumn{2}{|c|}{ Vertical level } \\
\hline & & & $\mathrm{n} / \mathrm{cm}^{2}$ & $\mathrm{vmd} \mu \mathrm{m}$ & $\mathrm{n} / \mathrm{cm}^{2}$ & $\mathrm{vmd} \mu \mathrm{m}$ \\
\hline \multirow{9}{*}{$\begin{array}{c}\text { Taral motor } \\
\text { sprayer } 2\end{array}$} & \multirow{3}{*}{ Left } & Upper & 39 & 249 & 0 & 0 \\
\hline & & Lower & 0 & 0 & 0 & 0 \\
\hline & & Average & 20 & 124 & 0 & 0 \\
\hline & \multirow{3}{*}{ Right } & Upper & 142 & 223 & 41 & 263 \\
\hline & & Lower & 17 & 356 & 37 & 235 \\
\hline & & Average & 80 & 289 & 57 & 249 \\
\hline & \multirow{3}{*}{ Middle } & Upper & 121 & 273 & 51 & 229 \\
\hline & & Lower & 33 & 233 & 96 & 257 \\
\hline & & Average & 77 & 253 & 60 & 243 \\
\hline \multirow{9}{*}{$\begin{array}{c}\text { Taral motor } \\
\text { D5-45 }\end{array}$} & \multirow{3}{*}{ Left } & Upper & 0 & 0 & 0 & 0 \\
\hline & & Lower & 138 & 237 & 54 & 243 \\
\hline & & Average & 69 & 118 & 27 & 121 \\
\hline & \multirow{3}{*}{ Right } & Upper & 111 & 227 & 42 & 193 \\
\hline & & Lower & 78 & 250 & 48 & 166 \\
\hline & & Average & 95 & 239 & 45 & 180 \\
\hline & \multirow{3}{*}{ Middle } & Upper & 219 & 254 & 144 & 220 \\
\hline & & Lower & 0 & 0 & 192 & 288 \\
\hline & & Average & 110 & 127 & 168 & 254 \\
\hline \multirow{9}{*}{$\begin{array}{c}\text { Taral motor } \\
\text { D8-45 }\end{array}$} & \multirow{3}{*}{ Left } & Upper & 60 & 211 & 42 & 287 \\
\hline & & Lower & 90 & 254 & 62 & 283 \\
\hline & & Average & 75 & 232 & 52 & 285 \\
\hline & \multirow{3}{*}{ Right } & Upper & 178 & 308 & 186 & 294 \\
\hline & & Lower & 175 & 309 & 196 & 318 \\
\hline & & Average & 177 & 309 & 191 & 306 \\
\hline & \multirow{3}{*}{ Middle } & Upper & 138 & 371 & 105 & 277 \\
\hline & & Lower & 129 & 315 & 75 & 311 \\
\hline & & Average & 134 & 343 & 90 & 294 \\
\hline \multirow{6}{*}{$\begin{array}{l}\text { Conventional } \\
\text { motor }\end{array}$} & \multirow{3}{*}{ Left } & Upper & 265 & 435 & 306 & 383 \\
\hline & & Lower & 264 & 409 & 262 & 300 \\
\hline & & Average & 264 & 422 & 284 & 341 \\
\hline & \multirow{3}{*}{ Right } & Upper & 146 & 365 & 166 & 308 \\
\hline & & Lower & 143 & 324 & 210 & 367 \\
\hline & & Average & 144 & 344 & 188 & 337 \\
\hline
\end{tabular}


Date in Table (5) indicate that the estimated drift was the minimum in the case of using taral motor sprayer operture $2(3 \%)$ followed by taral motor sprayer with three Tee-Jet noozles D5-45 (14.2) while taral motor sprayer with three Tee-Jet nozzles D8-45 the drift was (19.4\%) and conventional motor sprayer (31.7). the obtained results agree with courshee (1957) who stated that the most important controllable factor influencing drift is dropletssize. Maximum estimated deposits of spray solution on the tree was detected in the case of using taral motor sprayer with three Tee-Jet nozzles D5-45 (85.8 \%).

Results also agree with Watoon and Wolf (1985) who found that deposition uniformity was improved with the air carrier method, followed by tral motor sprayer with three Tee-Jet nozzles D8-45 (80.5\%), conventional motor sprayer (36.4\%) and taral motor sprayer aperture 2 (32\%).

Considering the relation between spray volume and occurred drift it was clear that there was positive relationship between the used spray volume and occurred drift. Conventional motor sprayer caused the highest spray volume which resulted in the highest drift. Taral motor sprayer with three Tee-Jet nozzles D8-45 which used as medium spray volume caused lower percentage for drift followed by Taral motor sprayer with three Tee-Jet nozzles D8-45 which relatively gave the lowest drift achieving the highest efficiency. These results lead us to conclude that, the conventional motor sprayer was the most pollutant spray unit comparing with the modified spray unit Taral motor sprayer with three Tee-Jet nozzles d5-45, (430l/fed.) which has the superiority in minimizing the time of spraying reducing spray volume with minimum limit of pollution.

Table 5. Estimated deposits of spray solution average and drift spray by certain ground spray equipments.

\begin{tabular}{|l|c|c|}
\hline \multirow{2}{*}{ Ground spray equipment } & \multicolumn{2}{|c|}{ Drift $\left(\mathrm{n} / \mathrm{cm}^{2}\right) \%$} \\
\cline { 2 - 3 } & On the tree & Drift spray \\
\hline Taral motor aperture2 & 32.1 & 3.17 \\
\hline Taral motor (D5-45) & 85.8 & 14.21 \\
\hline Taral motor (D8-45) & 80.53 & 19.47 \\
\hline Conventional motor & 36.46 & 31.77 \\
\hline
\end{tabular}

Comparing the three accepted sprayers its obivous that convetional motor sprayer used twice spray volume and subsequently twice spray material (pesticides) as the modified sprayers. Taral motor sprayer with three Tee-Jet nozzles D8-45 is in between. 
Conserzing the last sprayer solution on the ground (which is the source of soil pollution) and the sprayer solution drift (which is the source of air pollution). The obtained data are in agreement with Courshee (1960) who reported that, up to $80 \%$ of the total pesticides applied to plants might eventually reach the soil. Also the data are in paralled with Abou Setta (1981). Also this agree with Gabir et. al. (1981) who found that with the high volume, however the droplet size ranges from 600-1000 $\mu \mathrm{m}$, leads to run off problems and drastic 1000 of chemicals. Conventional motor sprayer gave the highest lost of sprayer solution on the ground and drift followed by Taral motor sprayer with three Tee-Jet nozzles D8-45 and the least by Taral motor sprayer with three Tee-Jet nozzles D5-45.

The presented results indicated the superiority of the tested Taral motor sprayer with three Tee-Jet nozzles D5-45 offer the other tested other sprayers and that's agree with Randal (1971) who found that the high air volume in pneumatic sprayers produced the most uniform deposits throughout a tree when traveling at the slower grounds speed. On the other hand results disagree with Richard et. al. (1977) who found that the spray deposition efficiency of orchard air blast sprayer was low and greatly influenced by droplet size, but in harmony with Abou Setta (1981) who considered the modified spray gun (D7-45) (1200/fed.) as the most economical practical and ecologically satisfactory technique in that investigation.

Modified Taral motor sprayer with three Tee-Jet nozzles D5-45 knapsack motor sprayer (430 l/fed.) proved to minimize the time of spraying, reducing spray volume and pollution, which agree with Abou Setta (1981).

\section{REFERENCES}

1. Abd-El Moati, M. I. 1981. Evulation of the present ground spraying techniques used for controlling certain cooton pests in Egypt. M. Sc. Tesis., Ain Shams Univ., Egypt, 71 PP.

2. Abuo-Setta, M. M. 1981. The influence of certain spray parameters on the efficiency of insecticide for controlling scale insects on citrus trees. M. Sc. Thesis, Faculty of Agriculture, Ain Shams university, Egypt, 78 PP.

3. Amberg, A. A. and B. J. Butler. 1970. High speed photography as a tool for spray droplet analysis. Trans Amirican Society Agricultural Engineers, 13(5): 547-556.

4. Anonymous. 2000. Agriculture Economic and statics Department, Ministry of Agriculture, Egypt: 220.

5. Courchee, R. J. 1957. Small volume spraying machinery for fruit trees. J. Agric. Engng. Res., 2(3): 198-208. 
6. Courchee, R. J. 1960. Some aspect of the application of insecticides. Ann. Rev. Ent; (5): 327-52.

7. Dean, H. A., E. L. Wilson; J. C. Bailey and L. A. Richel. 1961. Fluorescent dye technique for studying of spry deposit on citrus. J. Econ. Ent; 54(2) : 333-340.

8. Gaber, I; Z. H. Zidan and M. A. Hindy. 1981. Qualitative estimation of the influence of atomization rate of application and flight attitude on the performance pf aerial spraying of Sumicidin in cotton fields. Bull. Ent. Soc. Egypt, Econ. Ser; 12: 215-26.

9. Gabir, I.; Z. H. Zidan, E. Ahallah and M. A. Hindy. 1982. Calibration and evaluation of the performance of certain hydraulic nozzle types under laboratory conditions, Research Bulletin of Faculty Agriculture. Ain Shams University, Egypt, 1738: 1-17.

10. Mass, W. 1971. Field trials and evolution N. V. Philips. Duphar crop protection division, Amsterdam-Holland 180 pp.

11. Mcmechan, A. D. and G. D. Havorson. 1977. Air-blast orchard sprayers an operation and maintenance manual. Agricultural Canadian, 1625: 24 Pp.

12. Randal, J. M. 1971. The relation ships between ail volume and pressuer on spray distribution in fruit trees. J. Agric. Engng. Res. 16 (1):1-31.

13. Reichard, D. L.; H. J. Retzer; L. A. Lilijedahl and F. R. Hall. 1977. Spry droplet size distribution delivered by air blast orchard reprayers. Trans. Am. Soc. Agric. Engrs; 20 (2): $232-7$.

14. Waston, D. G. and R. L. Wolf. 1985. Air carrier technique for new crop spraying applications. Trans American Society Engineers, 28(5): 1445-1448. 


\section{التوزيع الكيفى لمتبقيات الرش على اثجار الزيتون باستخدام بعض وسائل الرش الارضى لمكافحة حشرة البرقوق القشرية}

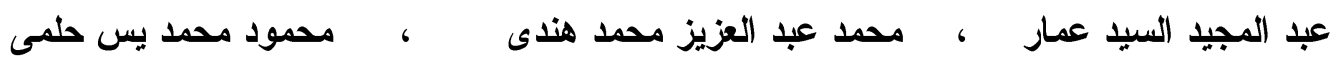
قسم بحوث تكنولوجيا الرش - معهر بحوث وقاية النباتات- مركز البحوث الزرراعية - الدقى جيزة.

تهدف هذه الدر اسة لتقييم كفاءة عدد من آلات الرش واستخدام بعض المبيدات بهدف مكافحة

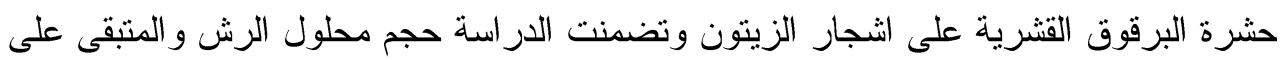
اشجار الزيتون ومصادر التلوث التى تشمل الفاقد من المبيد على التزبة و المنجرف بالهو اء. وكانت آلات الرش المختبرة هى موتور الرش التقليديى بمسدس الرش الهيدروليكى ( 860 لتر /فدان)

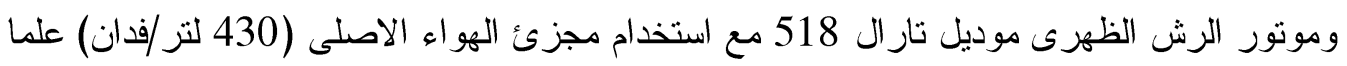

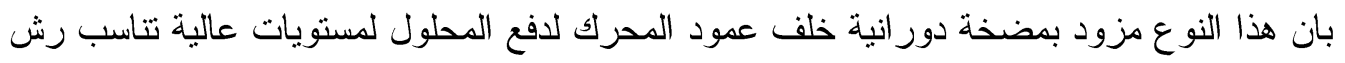

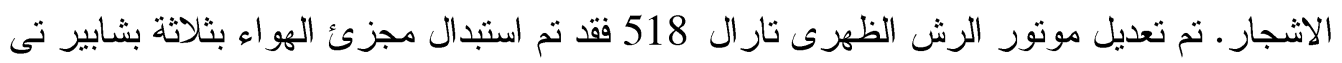
جيت (دى 5-45 او دى 8-45 ، 430 لتر/فدان او 495 لتر / فدان على التو التى ) و التى تم تثبيتها بصورة عمودية على تيار الهواء. فى حالة التعديل دى 5-45 فقد نم استخدام موتور الرش التقليدى كمصدر لضغط محلول

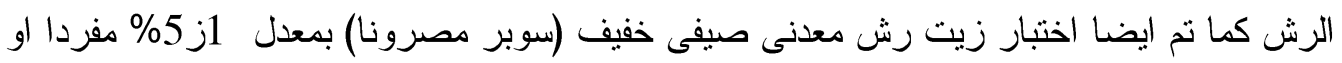

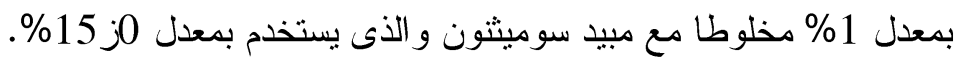

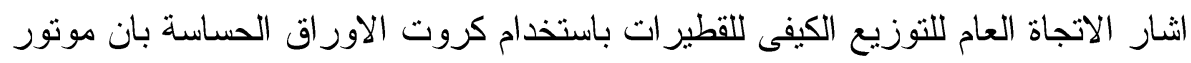

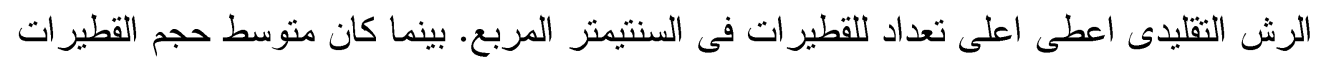

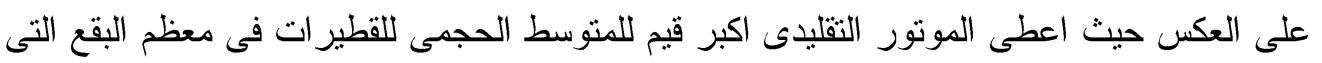
تم قياسها.

بمقارنة وحدات الرش الثلاثة اتضح ان الموتور التقليدى يستهلك ضعف حجم محلول الرش

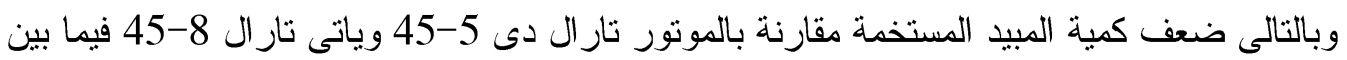
الاثنين.

اما الفاقد من المبيد على الارض و المنجرف بالهواء فقد اعطى موتور الرش التقليدى اعلى

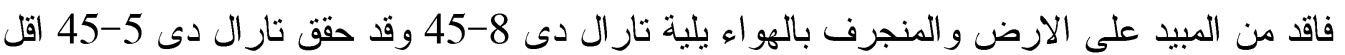

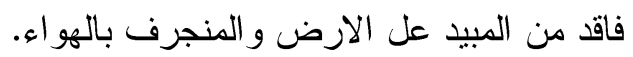

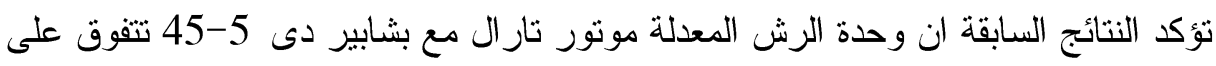

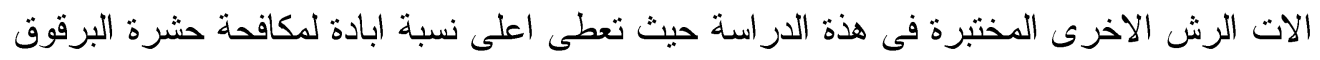
القشرية تحت الظروف المصرية مع اقل تلوث للبيئة. 